\title{
Red Guava Juice (Psidium guajava L.) Reduce Oxidative Stress of Toll Gate Collector
}

\author{
Riva Mustika Anugrah ${ }^{{ }^{*}}$, Sugeng Maryanto ${ }^{2}$, Kusmiyati Tjahjono ${ }^{3}$, Martha Irene Kartasurya ${ }^{4}$ \\ 1,2Nutritional Science, Faculty of Health, Ngudi Waluyo University, Jl. Diponegoro No. 186, \\ Ungaran District, Indonesia 50512 \\ ${ }^{3}$ Biochemistry Faculty of Medicine, Diponegoro University, Jl. Prof. H. Soedarto, S. H., Tembalang, \\ Semarang, Indonesia 50275 \\ ${ }^{4}$ Public Health Nutrition Department, Faculty of Public Health, Diponegoro University Indonesia, \\ Jl. Prof. H. Soedarto, S. H., Tembalang, Semarang, Indonesia 50275 \\ Email: rivamustika86@gmail.com
}

Submitted: March 15, 2017; Acceptance: August 20, 2019

\begin{abstract}
Exposure to air pollution can increase the occurrence of oxidative stress. Research showed that guava can reduce oxidative stress in Sprague Dawley rats. This experiment investigated the effect of red guava juice on oxidative stress in toll collectors. The subjects were 20 toll collectors in the treatment group and 20 in the control group. The treatment group received $250 \mathrm{~mL}$ red guava juice for 21 days while the controls did not receive anything. Malondialdehyde (MDA) was measured with thiobarbituric acid (TBA) reaction, food consumption was measured by $3 \times 24$ hours' recall. The data were analyzed by paired t-test, Wilcoxon test, independent t-test, Mann Whitney test, and general linear model. The results showed that the effect of red guava juice on the MDA level was significant in the treatment group $(p<0.05)$. A multivariate analysis showed that the effect of red guava juice to MDA level was significant after controlled by age, carbohydrate intake and initial conditions $(p<0.05)$. Red guava juices of $250 \mathrm{~mL}$ for 21 days could reduce malondialdehyde (MDA) levels of toll collectors.
\end{abstract}

Keywords: Red guava juice, malondialdehyde, toll collector, oxidative stress

\section{INTRODUCTION}

The increase number of vehicles is a source of air pollution, the high activities of vehicles contribute to $70 \%$ of air pollution. The results of vehicle combustion in the form of diesel and gasoline can cause air pollution, namely carbon monoxide (CO), Polycyclic Aromatic Hydrocarbon (PAH), nitrogen oxides (NOx) and sulfur dioxide (SOx), dust particulates and lead (Nanny and Gunawan, 2010). Environmental Agency of Central Java reported that Polycyclic Aromatic Hydrocarbon (PAH) is the highest source of air pollution in Semarang. Continuous Polycyclic Aromatic Hydrocarbon (PAH) exposure can cause oxidative stress (Eom et al., 2013).

The exposure to air pollution from the combustion engine vehicles caused oxidative stress in the body. Components of air pollution such as ozone, sulfur, nitric oxides and carbon monoxide generate environmental aerosols which cause reactive oxygen species (ROS) production in erythrocytes and lipid peroxidation. Lipid peroxidation leads to inflammation in the lungs, vascular and heart tissue (Lodovici and Bigagli, 2011). Lipid peroxidation is a mechanism of cell injury characterized by high malondialdehyde production (Geurard, 2010).

The toll gate collector is one type of work that has a very strong risk of being exposed to air pollution released by vehicles. Previous study showed that toll gate collector had a high risk of oxidative stress as indicated by the average malondialdehyde (MDA) levels of toll gate collector was $5.76 \mathrm{nmol} / \mathrm{L}$, this level was higher than the malondialdehyde level (MDA) control which is $3.07 \mathrm{nmol} / \mathrm{L}$ (Campen and Lund, 2012). Antioxidants, especially natural antioxidants, are needed to prevent or reduce chronic diseases by free radicals. One source 
of natural antioxidants is red guava which is very useful for body health. Red guava is one of the tropical fruits that is very rich in antioxidants compared to other fruits (Zabidah, 2011). The study on Sprague Dawley rats showed that intervention $0,20 \mathrm{~g}$ extract of red guava for 14 days can reduce malondialdehyde (MDA) levels (Chao, 2013).

Guava fruit contains vitamin C 3-6 times higher than citrus fruits (50-300 mg/100 g of fresh weight), containing polyphenol compounds (Gallic acid, catechin, trancinnamic acid, ferulic acid and vanillic acid) beta carotene and lycopene which can prevent lipid peroxidation processes, protein damage, nucleic acid breakdown caused by the presence of reactive oxygen species (ROS) (Elmouttaleb, 2012). Guava fruit contains other phytochemical substances such as quercetin, guajaverin, leukocyanidin and elagic acid. Quercetin is a flavanoid compound from the flavonol group. The antioxidant activity of quercetin is stronger than vitamin $C$ and vitamin $E$, quercetin was able to reduce plasma MDA levels (Sudjarwo, 2011). This study aimed to prove the effect of red guava juice giving (Psidium guajava L.) to malondialdehyde (MDA) levels of toll gate collector.

\section{RESEARCH METHOD}

Randomized controlled trial was conducted on 43 subjects of toll collectors from 3 toll gates in Semarang City Central Java Indonesia, 21 subjects in the treatment and 22 subjects in the control groups. The analysis was done only to 20 subjects on treatment group and 20 subjects on control groups who finished the study.

Red guava juice was made from $120 \mathrm{~g}$ of red guava plus $200 \mathrm{~mL}$ of water and $4 \mathrm{~g}$ sorbitol to produce $250 \mathrm{~mL}$ of red guava fruit juice contain $60 \mathrm{mg}$ of Vitamin $\mathrm{C}$, it can meet the requirement of body pool vitamin $\mathrm{C}$ in other to stable in the blood. Nutrient analysis test at food technology laboratory Unika Soegijapranata Semarang showed vitamin $C$ content of guava juice which $24 \mathrm{mg} / 100 \mathrm{~mL}$. The guava juice was given every day for 21 days. All of the subjects in the treatment group complied to the intervention and the control group did not received anything.

MDA was measured by tiobarbituric acid-base reaction (TBA) which form colored compounds MDATBA2 and absorb light at length of $532-534 \mathrm{~nm}$ in a spectrophotometer. The results were expressed as mean \pm SD. Statistical analysis was performed by paired t-test, wilcoxon test, independent t-test, mann whitney test and general linear model. A p value of < 0.05 was considered statistically significant. Data on food consumption were gathered through $3 \times 24$ hours recall. Ethical clearance was approved from the Ethical Committee of Faculty of Medicine, Diponegoro University with the number of $945 / E C / F K-R S D K / I X / 2016$. All the subjects signed the Informed Consent forms.

\section{RESULTS AND DISCUSSION}

This study was carried out on 43 subjects, but at the end of this study 3 subjects were dropout. The characteristic of the subjects is described in Table 1. All toll gate collectors worked during day times normally in 8 hour work shifts per day for at least 5 days a week. There were differences in age. The means age in the treatment group was six years older than the control group.

The research showed that increasing age related to oxidative stress which results in disruption of cell metabolism, and stimulates cell mutations (Winarsi, 2013). Age was related to lipid peroxidation, MDA levels was higher on the elderly compared to adults (Akila, 2007). There were no differences in BMI and the number of cigarette between the treatment group and the control group. Most respondents in this study were male, $14(70 \%)$ on treatment group and 15 (75\%) on control group.

The results of statistical tests showed that there were no differences MDA levels in the smokers and nonsmokers. However, this study showed that there was a decrease in MDA levels by $8 \%$ in the treatment group. Meanwhile, in the control group, there was an increase $11.8 \%$. Antioxidants needed by someone who has a higher smoking habit than non-smokers, especially for the needs of vitamin $C$ in smokers must be added by 35 $\mathrm{mg}$ (Pacier, 2015). Antioxidants are needed to reduce the ROS formed by the presence of several chemicals contained in cigarettes. Red guava fruit juice containing $60 \mathrm{mg}$ of vitamin C increases the amount of vitamin C intake in the treatment group so it is proven that vitamin

Table 1. Characteristic of the subjects

\begin{tabular}{lccc}
\hline \multirow{2}{*}{ Characteristics } & $\begin{array}{c}\text { Treatment } \\
\text { group }(\mathrm{n}=20)\end{array}$ & $\begin{array}{c}\text { Control group } \\
(\mathrm{n}=20)\end{array}$ & \multirow{2}{*}{$\mathrm{p}^{*}$} \\
\cline { 2 - 3 } & Means \pm SD & Means \pm SD & \\
\hline Age (year) & $40.80 \pm 9.5$ & $34.75 \pm 11.6$ & 0.00 \\
BMI $\left(\mathrm{kg} / \mathrm{m}^{2}\right)$ & $24.30 \pm 4.2$ & $24.5 \pm 2,7$ & 0.48 \\
Gender $\mathrm{n}(\%)$ & & & \\
Male & $14(70)$ & $15(75)$ & \\
Female & $6(30)$ & $5(25)$ & \\
\hline
\end{tabular}

$\mathrm{p}^{*}$ : independent t-test 
Tabel 2. The differences in MDA levels based on smoking habits on treatment group and control group

\begin{tabular}{lccccc}
\hline \multirow{2}{*}{ Variable } & \multicolumn{2}{c}{ Treatment group $(\mathrm{n}=20)$} & \multicolumn{2}{c}{ Control group $(\mathrm{n}=20)$} & \\
& $\begin{array}{c}\text { Smokers } \\
(\mathrm{n}=10)\end{array}$ & $\begin{array}{c}\text { Non smokers } \\
(\mathrm{n}=10)\end{array}$ & $\begin{array}{c}\text { Smokers } \\
(\mathrm{n}=8)\end{array}$ & $\begin{array}{c}\text { Non smokers } \\
(\mathrm{n}=12)\end{array}$ & $\mathrm{p}$ \\
\cline { 2 - 5 } & Mean $\pm \mathrm{SD}$ & Mean \pm SD & Mean \pm SD & Mean \pm SD & \\
\hline $\begin{array}{l}\text { MDA levels before } \\
\text { treatment }(\mathrm{nmol} / \mathrm{mL})\end{array}$ & $12,66 \pm 0,64$ & $13,37 \pm 0,78$ & $13,29 \pm 0,77$ & $13,08 \pm 0,47$ & $0,51^{\mathrm{a}}$ \\
$\begin{array}{l}\text { MDA levels after } \\
\text { treatment }(\mathrm{nmol} / \mathrm{mL})\end{array}$ & $11,80 \pm 1,04$ & $12,04 \pm 0,53$ & $14,87 \pm 2,3$ & $13,321,4$ & $0,77^{\mathrm{b}}$ \\
\hline
\end{tabular}

$\mathrm{C}$ and other antioxidants contained therein can reduce free radicals and improve lipid profiles.

Table 3 showed there are no difference levels of fat and fiber intake between the groups. The level of Vitamin $A, C, E$ intake in the two groups were low compared to WHO recommendation which is about 5 servings/day, as they consumed low vegetables and fruits. The average level of fat intake between the groups were higher than Indonesian RDA. There were differences in the level of carbohydrate intake between the group, the treatment group has higher carbohydrate intake during the study.

The mean levels of malondialdehyde (MDA) in this study was higher $(13.09 \pm 0.69 \mathrm{nmol} / \mathrm{mL})$ than it was shown in previous studies on toll gate collectors in Turkey, which has malondialdehyde (MDA) of $5.76 \mathrm{nmol} / \mathrm{mL}$ (Arbak P, 2004). After the treatment, malondialdehyde (MDA) levels decreased from $13.01 \pm 0.78 \mathrm{nmol} /$ $\mathrm{mL}$ to $11.92 \pm 0.81 \mathrm{nmol} / \mathrm{mL}$ in the treatment group $(p=0,000)$, but there were no differences on MDA levels from $13.10 \pm 0.60 \mathrm{nmol} / \mathrm{mL}$ to $13.94 \pm 1.9 \mathrm{nmol} / \mathrm{mL}$ in the control group $(p=0.263)$. The complete results can be seen in Figure 2.

Vitamin $\mathrm{C}$ has a role in oxidation process by acting as a scavenger of reactive oxygen species

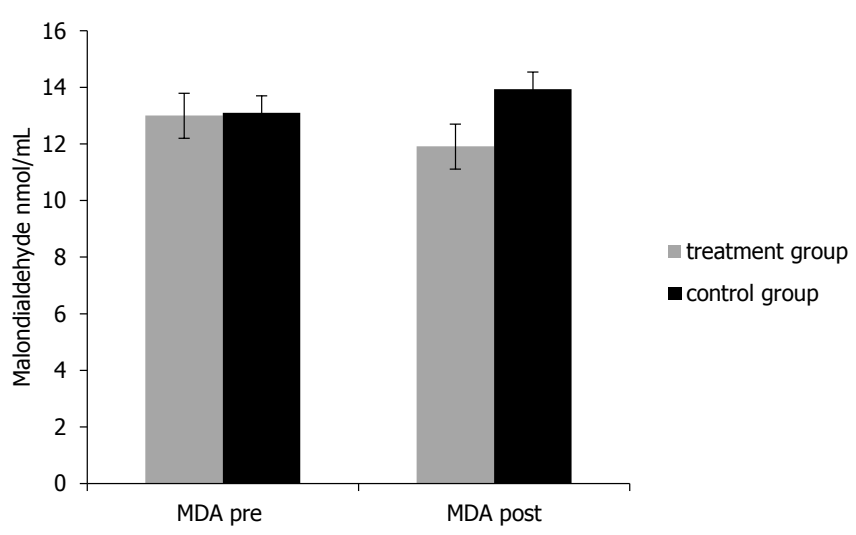

Figure 1. MDA levels on pre and post treatment in the treatment and control group before controlled for age, carbohydrate intake and baseline.

(ROS) (Murini et al., 2014). Serum levels of vitamin $\mathrm{C}$ in the body is determined by Vitamin $\mathrm{C}$ body pool (Sareen, 2009). Vitamin C supplementation at a dose of $60 \mathrm{mg} / \mathrm{d}$ will maximize the body pool of vitamin C, so that the levels of vitamin $C$ serum can maximize its function as antioxidant (Padayatty, 2003). Red guava juice containing $60 \mathrm{mg}$ of vitamin $\mathrm{C}$ has good benefit to reduce free radicals from air pollution. Vitamin $C$ is capable to capture the free radicals and it can donate

Table 3. Nutrient intake of the subjects

\begin{tabular}{lccc}
\hline Variabel (\%) & Treatment group $(\mathrm{n}=20)$ & Control group $(\mathrm{n}=20)$ & $\mathrm{p}$ \\
\cline { 2 - 3 } & Means \pm SD & Means \pm SD & $0.009^{\mathrm{a}}$ \\
Carbohydrat intake level & $82.38 \pm 17.09$ & $69.3 \pm 12.6$ & $0.296^{\mathrm{b}}$ \\
Fat intake level & $113.01 \pm 37.64$ & $140.47 \pm 92.7$ & $0.67^{\mathrm{a}}$ \\
Fiber intake level & $58.97 \pm 13.4$ & $57.27 \pm 11.59$ & $0.620^{\mathrm{b}}$ \\
Vitamin A intake level & $35.6 \pm 89.7$ & $41.17 \pm 74.39$ & $0.62^{\mathrm{b}}$ \\
Vitamin C intake level & $30.02 \pm 11.48$ & $27.50 \pm 10.50$ & $0.71^{\mathrm{a}}$ \\
Vitamin E intake level & $34.87 \pm 15.04$ & $36.76 \pm 17.69$ & \\
\hline
\end{tabular}

a Independent t-test

b Mann-Whitney 
Table 4. Effect of red guava juice (Psidium guajava L.) on MDA Levels after being controlled by age, carbohydrate intake and initial conditions

\begin{tabular}{|c|c|c|c|c|}
\hline \multirow[t]{2}{*}{ Variable } & \multicolumn{2}{|c|}{ Group } & \multirow[t]{2}{*}{ Adjusted R square } & \multirow[t]{2}{*}{$\mathrm{p}$} \\
\hline & Treatment group $(n-20)$ & Control group $(n=20)$ & & \\
\hline $\operatorname{MDA}(\mu \mathrm{M} / \mathrm{L})$ & $12,1 \pm 0,01$ & $13,6 \pm 0,01$ & 0,381 & 0,005 \\
\hline
\end{tabular}

electron groups such as enadiol group. Vitamin C can donate electrons to prevent the oxidation process, after giving electrons to the free radicals, Vitamin $\mathrm{C}$ oxidizes into semi dehydroascorbate acid which is relatively stable (Pacier, 2015; 9. Hermsdorff et al., 2012).

Red guava juice may reduce Malondialdehyde (MDA) levels due to the content of antioxidants. The antioxidants have a role in preventing lipid peroxidation which lead to the formation of Malondialdehyde (Romieu, 2008). Vitamin C is able to improve SOD levels because it can absorb superoxide free radicals and minimize the damage caused by oxidative stress. These antioxidants react with superoxide to form hydrogen peroxide and oxygen which minimize the work of SOD so that the SOD activity inhibiting free radicals becomes more efficient (Moreira, 2014).

Red guava contained polyphenols and carotenoids as antioxidant phytochemicals. Polyphenol can prevent radical chain reactions in intra and extracellular biochemical reactions through radical scavenging activities which are related to the substitution of hydroxyl groups in the aromatic rings of phenolics (Norshazila, 2010; Zhang, 2015). Guava also contain quercetin, which has a potent antioxidant activity due to its ability to scavenge free radicals and bind transition metal ions. These properties of quercetin allow it to inhibit lipid peroxidation (Sudjarwo, 2011).

General Linear Model (GLM) analyses were performed to include the counfounding variables which were age, level of carbohydrate intake and the baseline level. The mean of malondialdehyde levels was $12.1 \pm 0.01 \mathrm{nmol} / \mathrm{mL}$ in the treatment group and $13.6 \pm 0.01 \mathrm{nmol} / \mathrm{mL}$ in the control group. MDA levels of respondents after being controlled by age, carbohydrate intake and initial conditions showed significant results $(p<0.05)$. Statistically, age, carbohydrate intake, and initial conditions in the treatment group had significant differences with the control group. The effect of age, carbohydrate intake and initial conditions on MDA levels was $38.1 \%$ and the remainder was influenced by other factors. One of the factors causing high MDA levels at the toll gate collector can be caused by regular exposure to air pollution accompanied by low intake of vitamins $A$, $\mathrm{C}$ and $\mathrm{E}$ as natural antioxidants.

\section{CONCLUSION}

The results of this study indicate that the subjects' intake of vitamin $A, C$ and $E$ is lower than the nutritional adequacy rate of Indonesians. The treatment group in this study had an older age average and higher smoking habits than the control group, both of which were very influential on MDA levels, but after administration of guava juice, MDA levels could decrease. On the other hand, in the control group whose age was younger and smoking habit was lower, MDA levels increased. Providing $250 \mathrm{~mL} /$ day guava fruit juice containing $60 \mathrm{mg}$ of vitamin $\mathrm{C}$ for 21 days can reduce MDA levels at the toll gate collector. This analysis has been strengthened by conducting multivariate tests taking into account confounding factors, namely age and carbohydrate intake and MDA levels initially so that it has stronger research results.

\section{ACKNOWLEDGMENTS}

The author thanked to all of the toll gate collectors who participated in this study. The author also thanked to Ngudi Waluyo foundation for funding this study.

\section{CONFLICT OF INTEREST}

The authors declare there is no conflict of interest.

\section{REFERENCES}

Akila, V. Prashant, Harishchandra, H., D'souza, V., D'souza, Benedicta. (2007). Age Related Changes In Lipid eroxidation and Atioxidant in Elderly People. Indian Journal of Clinical Biochemistry, 22(1), 131-134.

Arbak, P., Yavuz, O., Bukan, N., Balbay, O., Ulger, F., Annakkaya, A. N. (2004). Serum oxidant and antioxidant levels in diesel exposed toll collectors. J Occup Health, 46(4), 281-88. http://doi:10.1539/joh.46.281

Campen, M. J. and Lund, A. M. R. (2013). Mechanism Linking Traffic Related air Pollution and Atherosclerosis. Nat/ Institue Health, 18(2), 150-160. http://doi:10.1097/ MCP 0B013e32834f210a 
Central Java Environment Agency. (2015). Report of Air Quality Monitoring in 35 District/City, 45-48.

Chao, H., Wu, P., Lo, D., Wu, W., Wu, M. (2013). Effect of guava (Psidium guajava Linn.) fruit water extract on lipid peroxidation and serum lipid profiles of streptozotocinnicotinamide induced diabetic rats. Moleculs. 7(32):2299-2305. http://doi:10.5897/AJPP2013.3698

Eom SY, Yim DH, Moon SI, Youn JW, Kwon HJ, Oh HC, Yang J], Park SK, Yoo KY, Kim HS, Lee KS, Chang SH, Kim YD, Kang JW, Kim H (2013). Polycyclic Aromatic Hydrocarboninduced Oxidative Stress, Antioxidant Capacity, and the Risk of Lung Cancer : International Journal of Cancer Research and Treatment ,3089-3097.

Elmouttaleb, A. T. A., Mostafa, U. E. (2012). Effect of Tomato and Guava juices on Oxidative Stress in Rats after Strenuous Exercise. JJBS, 5(3), 167-174. http://doi: 10.3109/13880209.2012.688057

Guéraud, F. (2010). Lipid Peroxidation Originating $a, \beta-$ unsaturated Aldehydes and Their Metabolites as Biomarkers. In Biomarkers for Antioxidant Defense and Oxidative Damage:Principles and Practical Applications, Iowa: Wiley-Blackwell, 117-121.

Hermsdorff HH, Barbosa KB, Volp AC, Puchau B, Bressan J, Zulet MÁ, Martínez JA.(2 012). Vitamin C and fibre consumption from fruits and vegetables improves oxidative stress markers in healthy young adults. British Journal of Nutrition (107), 119-127. http://doi:10.1017/ S0007114511004235

Kusminingrum, N. and Gunawan, G. (2010). Effects air pollution in Urban Road Vehicle Java and Bali. Road and Bridge Research and Development Centre.

Lodovici, M. and Bigagli, E. (2011). Oxidative Stress and Air Pollution Exposure. Journal of Toxicology. Volume 2011 9 pages http://doi:10.1155/2011/487074

Moreira, M. A., Nascimento, M. A., Bozzo, T. A., Cintra, A., Da Silva, S. M., Dalboni, M. A.(2014). Ascorbic acid reduces gentamicin-induced nephrotoxicity in rats through the control of reactive oxygen species. Clin Nutr., 33(2), 296-301. https://doi: 10.1016/j.clnu.2013.05.005
Murini (2014). The effect of red guava fruit juice (Psidium guajava L.) on lipid profile and atherosclerosis in Rats. Faculty of Medicine Gajah Mada University.

Norshazila S, Syed ZI, Musthapa SK, Aisyah MR, Kamarul RK. (2010). Antioxidant levels and activities of selected seeds of Malaysian Tropical Juices. Mal J Nutr 16(1): 149-159

Pacier, C. and Martirosyan, D. M. (2015). Vitamin C : optimal dosage, supplementation and use in disease prevention. Funct Foods Heal Dis, 5(3), 89-107.

Padayatty S ${ }^{1}$, Katz A, Wang Y, Eck P, Kwon O, Lee JH, Chen S, Corpe C, Dutta A, Dutta SK, Levine M. (2003). Vitamin $\mathrm{C}$ as an antioxidant: evaluation of Its role in disease prevention. J Am Coll Nutr 22(1), 18-35. https:// doi: $10.1080 / 07315724$.

Romieu, I., Kunzli, N., Sunyer, J. (2008). Air pollution, oxidative stress and dietary supplementation: a review. Eur Respi J, 31(1):179-196. https://doi: 10.1183/09031936.00128106.

Sareen, S., Gropper, J. L. S., Groff, J. L. (2009). Advance Nutrition and Human Metabolism. Chapter 9, 312-320. 5th ed. Canada: Wardsworth Cengage Learning.

Sudjarwo SA.(2011). Mechanisms of endothelial cell protection by quercetin in hypercholesterolemia. Research in Pharmaceutical Biotechnology Vol. 3(9), pp. 123-127.

Zabidah AA, Kong KW and Amin I (2011). Antioxidant properties of tropical juices and their effects on in vitro hemoglobin and low density lipoprotein ( $L D L$ ) oxidations. International Food Research Journal, (18), 549-556.

Zhang YJ, Gan RY, Li S, Zhou Y, Li AN, Xu DP, Li HB (2015). Review Antioxidant Phytochemical for the prevention and Treatment of Chronic Disease. MDPI Molecules. Nop 27;20(12):21138-56. https://doi: 10.3390/ molecules201219753. 